\title{
POLA BAKTERI AEROB PADA PASIEN DENGAN DIAGNOSIS OTITIS MEDIA SUPURATIF AKUT DI POLIKLINIK THT-KL RSUP. PROF. DR. R. D. KANDOU MANADO
}

\author{
Nur Dinih Mamonto \\ John Porotu'o \\ Olivia Waworuntu \\ ${ }^{1}$ Kandidat Skripsi Fakultas Kedokteran Universitas Sam Ratulangi \\ ${ }^{2}$ Bagian Mikrobiologi Fakultas Kedokteran Universitas Sam Ratulangi \\ Email:dinyhmamonto_15@yahoo.com
}

\begin{abstract}
Otitis media is an inflammation of part or all of the middle ear mucosa. Eustachi tube obstruction is a basic causative factor in acute otitis media. The tract infections can cause swelling around the channel, crunch, and as a result formed pus in the middle ear. The purpose of research is to determine the pattern of aerobic bekteri in patients diagnosis of Acute suppurative otitis media in Polyclinic Hospital THT-KL. PROF. dr. R. D. Kandou Manado. This study is a descriptive study population of all patients in the diagnosis of acute suppurative otitis media by making a purposive sampling technique obtained 20 samples of patients with acute suppurative otitis media. Then, 20 samples were collected for microbiological examination by culture techniques and biochemical tests. The results of this study were 20 patient samples obtained Acute suppurative otitis media age 0-5 years (8 samples; 42\%), 6-10 years (6 samples; $27 \%), 11-20$ years ( 1 sample; $5 \%), \geq 20$ years (5 samples; $26 \%$ ); male gender - male (9 samples; 55\%), women (9 samples; 45\%). Twenty samples examined, all showed growth of bacteria and obtained seven bacterial species and one species of candida. 3 obtained from the gram-positive bacteria, namely Streptococcus sp culture (7 samples; 35\%), Staphylococcus sp (4 samples; 20\%), Bacilus subtilis (2 samples; 10\%) 4 gram-negative bacteria Enterobacter Aglomerans (2 samples; 10\% ), Enterobacter cloacae (1 sample; 5\%), Seretia Rubidaea (1 sample; 5\%), Proteus vulgaris (2 samples; $10 \%$ ), Candida (1 sample; 5\%). Conclusion The research found most bacteria causing acute suppurative otitis media, namely Streptococcus, the largest age group experienced acute suppurative otitis media, namely children's ( $0-5$ years).
\end{abstract}

Keywords: acute suppurative otitis media, aerobic bacteria

\begin{abstract}
Abstrak: Otitis media adalah peradangan sebagian atau seluruh mukosa telinga tengah. Obstruksi tuba eustachi merupakan suatu faktor penyebab dasar pada otitis media akut. Infeksi di saluran tersebut dapat menyebabkan pembengkakan di sekitar saluran, tersumbatnya saluran, dan sebagai hasilnya terbentuklah nanah dalam telinga tengah. Tujuan penelitian adalah untuk mengetahui pola bekteri aerob pada pasien diagnosis Otitis Media Supuratif Akut di Poliklinik THT-KL RSUP. PROF. dr. R. D. Kandou Manado. Penelitian ini merupakan penelitian deskriptif dengan populasi seluruh pasien yang di diagnosis Otitis Media Supuratif Akut dengan teknik pengambilan purposive sampling didapatkan 20 sampel penderita Otitis Media Supuratif Akut. Kemudian, 20 sampel dikumpulkan untuk dilakukan pemeriksaan mikrobiologi dengan teknik kultur dan uji biokimia. Hasil dari penelitian ini adalah 20 sampel pasien Otitis Media Supuratif Akut didapatkan umur 0 - 5 tahun (8 sampel; 42\%), 6 - 10 tahun (5 sampel; 27\%), 11 - 20 tahun (1 sampel; 5\%), $\geq 20$ tahun (5 sampel; 26\%); jenis kelamin laki - laki (9 sampel; 55\%), perempuan (9 sampel; 45\%). Duapuluh sampel yang diperiksa, seluruhnya menunjukkan pertumbuhan bakteri dan didapatkan 7 spesies bakteri dan 1 spesies
\end{abstract}


candida. Didapatkan 3 bakteri gram positif dari hasil kultur yaitu Streptococcus sp (7 sampel; 35\%), Staphylococcus sp (4 sampel; 20\%), Bacilus subtilis (2 sampel; 10\%) 4 bakteri gram negatif Enterobacter Aglomerans (2 sampel; 10\%), Enterobacter cloacae (1 sampel; 5\%), Seretia Rubidaea (1 sampel; 5\%), Proteus Vulgaris (2 sampel; 10\%), Candida (1 sampel; 5\%). Kesimpulan penelitian didapatkan bakteri terbanyak penyebab Otitis Media Supuratif Akut yaitu Streptococcus, dan kelompok umur terbanyak yaitu anak - anak (0 - 5 Tahun).

Kata kunci: otitis media supuratif akut, bakteri aerob

Otitis media adalah peradangan sebagian atau seluruh mukosa telinga tengah, tuba eustachi, antrum mastoid dan sel-sel mastoid. Telinga tengah biasanya steril, meskipun terdapat mikroba nasofaring dan faring. Secara fisiologik terdapat mekanisme pencegahan masuknya mikroba ke dalam telinga tengah oleh silia mukosa tuba eutachius, enzim dan antibodi. ${ }^{1}$ Obstruksi tuba eustachi merupakan suatu faktor penyebab dasar pada otitis media akut. ${ }^{1-8}$ Dengan demikian hilanglah sawar utama terhadap invasi bakteri, dan spesies bakteri yang tidak biasanya patogenik, dapat berkolonisasi dalam telinga tengah, menyerang jaringan dan menimbulkan infeksi. Bakteri yang seringkali ditemukan antara lain Streptococcus pneumoniae, Haemophilus influenzae, dan streptococcus beta-hemolitikus. Sejauh ini Streptococcus pneumoniae merupakan organisme penyebab tersering pada semua kelompok umur. $^{2-4}$

Otitis media supuratif akut (OMSA) adalah infeksi akut telinga tengah dalam waktu yang singkat. ${ }^{2}$ OMSA terjadi karena faktor pertahanan tubuh terganggu. Sumbatan tuba eustachi merupakan faktor penyebab utama dari otitis media. Karena fungsi tuba eustachius terganggu, pencegahan invasi kuman ke dalam telinga tengah juga terganggu, sehingga kuman masuk ke dalam telinga tengah dan terjadi peradangan. $^{1}$

Di Amerika Serikat 70\% anak - anak mengalami $\geq 1$ kali serangan OMSA sebelum usia 2 tahun. Di Indonesia sendiri, belum ada data akurat yang menunjukkan angka kejadian, insidensi, maupun prevalensi OMSA. OMSA merupakan penyakit yang sering di jumpai dalam praktik sehari-hari yang umumnya diawali dengan infeksi virus pada saluran pernapasan atas yang kemudian diikuti oleh invasi bakteri piogenik di telinga tengah. ${ }^{5}$

Tingginya kasus OMSA di Indonesia ini perlu menjadi perhatian khusus, sebab OMSA yang tidak ditangani secara adekuat dan tetap bertahan dapat berkembang menjadi bentuk yang lebih serius, yaitu Otitis Media Supuratif Kronik (OMSK), yang merupakan salah satu gangguan pendengaran. Usia merupakan salah satu faktor risiko yang cukup berkaitan dengan OMSA. Pada anak-anak berusia 6 tahun ditemukan prevalensi OMSA sebesar 4\%. ${ }^{3}$ Kasus OMSA sangat banyak terjadi pada anak -anak dibandingkan dengan kalangan usia lainnya. Kondisi ini disebabkan oleh posisi tuba Eustachius anak pada fase perkembangan telinga tengah cenderung lebih pendek, lebar, dan terletak horizontal. $^{2-3}$ Faktor lain yang dapat meningkatkan risiko OMSA yaitu infeksi saluran napas atas, pajanan pada asap lingkungan, polusi iritan dan bahan -bahan alergen, kurangnya waktu pemberian ASI esklusif dan pemberian makan dalam posisi terlentang pada anak, riwayat OMSA pada keluarga, kelainan kepala dan wajah, penurunan sistem imun, dan aliran balik dari lambung dan esophagus.

Berdasarkan angka kejadian yang cukup tinggi dan bervariasinya pola kuman pada penyakit otitis media supuratif akut sehingga penulis tertarik untuk melakukan penelitian mengenai pola bekteri pada penderita otitis media supuratif akut.

\section{METODE PENELITIAN}

Penelitian yang dilakukan bersifat deksriptif prospektif. Penelitian ini dilakukan pada bulan November 2014 Januari 2015. Sampel pada penelitian ini 
adalah 20 sampel pasien dengan diagnosis Otitis Media Supuratif Akut. Pengelolaan sampel dilakukan di Laboratorium Mikrobiologi Fakultas Kedokteran Universitas Sam Ratulangi dengan teknik kultur dan uji biokimia.

\section{HASIL PENELITIAN}

Penelitian ini dilakukan di Laboratorium Mikrobiologi Fakultas Kedokteran Universitas Sam Ratulangi Manado terhadap 20 sampel Otitis Media Supuratif Akut dengan kelompok umur terbanyak adalah umur 0 - 5 Tahun sebesar 8 sampel (42\%), 6 - 10 Tahun sebesar 6 sampel (27\%), 11 - 20 Tahun sebesar 1 sampel $(5 \%)$, dan $\geq 20$ tahun sebesar 5 sampel (26\%). Berdasarkan Gambar 1 dapat disimpulkan bahwa Otitis Media Supuratif Akut lebih sering menyerang anak - anak dibandingkan kalangan umur lainnya.

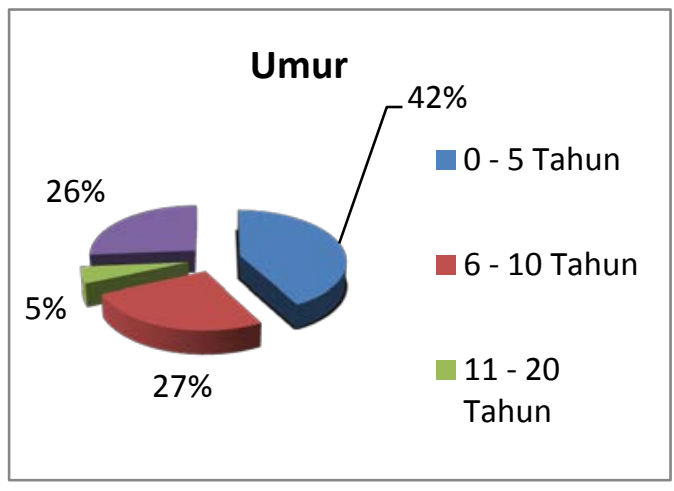

Gambar 1. Ditribusi sampel berdasarkan umur

Berdasarkan Gambar 2 didapatkan distribusi sampel berdasarkan jenis kelamin pada 20 pasien dengan jenis kelamin laki laki berjumlah 11 orang (55 \%) dan pasien dengan jenis kelamin perempuan berjumlah 9 orang ( $45 \%)$

Berdasarkan Gambar 3 yang disajikan dapat disimpulkan bahwa setelah dilakukan pewarnaan adanya pertumbuhan bakteri gram positif (13 sampel; 65\%), gram negatif (6 sampel; 30\%) dan Candida (1 sampel; 5\%) .

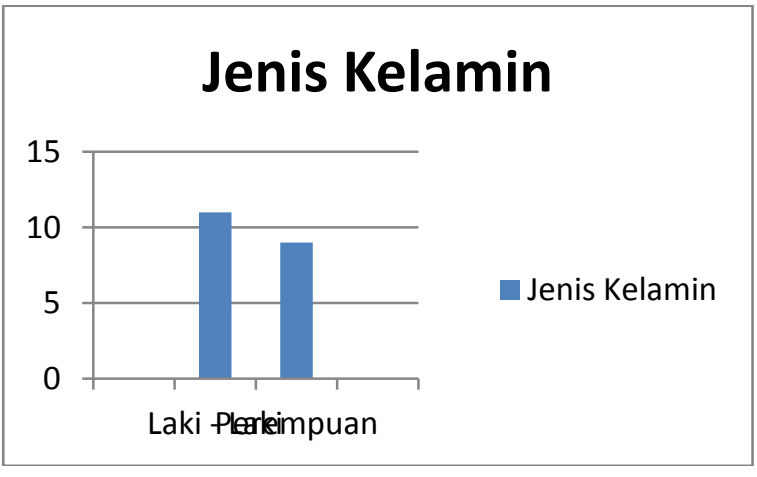

Gambar 2. Distribusi sampel berdasarkan jenis kelamin

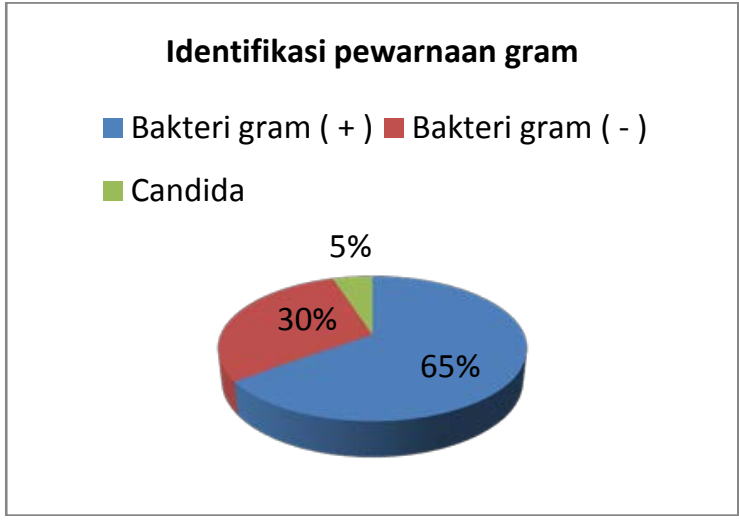

Gambar 3. Distribusi tabel berdasarkan pewarnaan gram

Tabel 1 menunjukkan hasil biakan bakteri pada pasien dengan diagnosis Otitis Media Supuratif Akut di Poliklinik THT KL RSUP. Prof. Dr. R. D. Kandou Manado dan didapati hasil yang terbanyak ialah Streptococcus sp sebanyak 7 (35\%), diikuti Staphylococcus sp sebanyak 4 (20\%).

Tabel 1. Hasil biakan mikroba terhadap sampel Otitis Media supuratif Akut

\begin{tabular}{lcc}
\hline \multicolumn{1}{c}{ Jenis Bakteri } & Jumlah & Presentase \\
\hline EnterobacterAglomerans & 2 & $10 \%$ \\
Streptococcus sp & 7 & $35 \%$ \\
Enterobacter cloacae & 1 & $5 \%$ \\
Staphylococcus sp & 4 & $20 \%$ \\
Seretia Rubidaea & 1 & $5 \%$ \\
Proteus Vulgaris & 2 & $10 \%$ \\
Bacilus subtilis & 2 & $10 \%$ \\
Candida & 1 & $5 \%$ \\
\hline Total & 20 & $100 \%$
\end{tabular}




\section{BAHASAN}

Berdasarkan pemeriksaan yang dilakukan terhadap 20 sampel pasien dengan diagnosis Otitis Media Supuratif Akut di Laboratorium Miokrobiologi Fakultas Kedokteran Universitas Sam Ratulangi, diperoleh 20 sampel seluruhnya menunjukkan pertumbuhan bakteri. Hasil biakan di temukan bermacam-macam spesies bakteri yakni 7 spesies bakteri dan 1 jamur. Bakteri yang ditemukan terdiri dari Enterobacter Aglomerans sebanyak 2 (10 \%), Streptococcus sp sebanyak 7 (35\%), Staphylococcus sp sebanyak 4 (20 $\%$ ), Seretia Rubia sebanyak 1(5\%) , ProteusVulgaris sebanyak 2 (10 \%), Enterobacter coclae sebanyak 1 (5\%), Basil subtilis sebanyak 2 (10 \%), dan 1 spesies jamur yaitu Candida sebanyak 1 (5\%). Hasil ini relatif sama dengan penelitian sebelumnya yang dilakukan (Kerschner, 2007) di mana bakteri penyebab OMSA tersering adalah Streptococcus Pneumoniea (40\%), diikuti oleh Haemophilus influenzae (25-30\%) dan Moraxella catarhalis (10-15\%). Kira-kira $5 \%$ kasus dijumpai patogen-patogen yang lain seperti Streptococcus pyogen (grup Ahemolytic), Staphylococcus aureus, dan organisme Gram negatif. Staphylococcus aureus dan organisme Gram negatif banyak ditemukan pada neonatus yang menjalani rawat inap di rumah sakit dan Haemophiluz influenzae sering ditemukan pada balita. Penelitian oleh Bluestone (2001) dalam Klein (2009) menyebutkan bahwa distribusi mikroorganisme yang diisolasi dari cairan tengah, dari 2807 orang pasien OMA di Pittsburgh Otitis Media Research Center, pada tahun 1980 sampai 1989 yakni Streptococcus Pneumonia (36\%), Haemophilus Influenzae (25\%), Moraxella catarhalis (15\%), Staphylococcus Aureus (5\%) dan Pseudomonas Aeruginosa (2\%) dan bakteri Gram negatif lainnya seperti Proteus sp, Citrobacter, dan Alcaligenes Faecalis. Hal ini juga sama dengan penelitian yang dilakukan oleh Osazuwa F, et al.2011. Dari hasil yang didapat, terdapat beberapa jenis bakteri yang mirip dengan jenis bakteri yang ditemukan pada penelitian diatas yakni Streptococcus $s p$, Staphylococcus Aureus, dan bakteri Gram negatif lainnya. Perbedaan jenis bakteri yang ditemukan dapat disebabkan oleh beberapa faktor diantaranya adalah metode penelitian, alat dan media penelitian yang digunakan, kondisi ruangan dan udara serta kuantitas koloni bekteri yang tumbuh berbeda.

Terdapatnya bakteri-bakteri dalam sampel yang merupakan suatu bentuk infeksi nosokomial dikarenakan adanya kontaminasi yang bersifat eksogen dari ruangan tempat pengembilan sempel. Bacilus Subtilis merupakan bakteri kontaminan yang terdapat di udara, tanah dan kompos tanah. Keberadaan bakteri Basil Subtilis dikarenakan adanya kontaminasi sampel oleh bakteri ini lewat udara dan peneliti menyimpulkan bahwa bakteri ini terkontaminasi dari teknik pengambilan sampel.

Pada penelitian ini juga ditemukan pertumbuhan mikroba jenis Candida, sama dengan penelitian sebelumnya yang dilakukan Sedjawidada et al, bahwa koloni jamur pada OMSA perforasi sebesar 44\%. akan tetapi tidak dibahas lebih lanjut dalam penelitian ini karena Candida tergolong fungi yang bukan merupakan cakupan dari penelitian ini. ${ }^{8}$

\section{SIMPULAN}

1. Terdapat 7 spesies bakteri dan 1 spesies Candida pada 20 sampel pemeriksaan mikrobiologi. Bakteri yang berhasil di Identifikasi adalah Enterobacter Aglomerans sebanyak 2 (10\%), Streptococcus sp sebanyak 7 (35 \%), Candida sebanyak 1 (5\%), Staphylococcus aureus sebanyak 4 (20 \% ), Seretia Rubia sebanyak (5\%) 1, Proteus Vulgaris sebanyak 2 (10\%), Enterobacter coclae sebanyak 1 (5 $\%)$, Basil subtilis sebanyak 2 (10\%).

2. Otitis Media Supuratif Akut lebih sering menyerang anak-anak dibandingkan dengan kelompok umur lainnya. 


\section{DAFTAR PUSTAKA}

1. Djafaar ZA dkk. Kelainan telinga tengah.Dalam: Soepardi EA, Iskandar $\mathrm{N}$, Bashirudin J, Restuti RD, Ed. Buku ajar ilmu kesehatan telingan hidung tenggorok kepala leher. Edisi keenam. Jakarta: FKUI, 2007. h.6568

2. Adams G L, Boies LR, Higler PA. Buku Ajar Penyakit Telinga Hidung Tenggorok. Penerbit: Buku. Kedokteran EGC, Jakarta, 1994; hal. $89-100$

3. Herawati S. Ilmu Penyakit Telinga Hidung Tenggorok. EGC. Jakarta. 2003

4. Brooks. G.F, Butel J.S, Morse S.A.

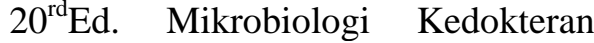
Jawetz, Melnick, \& Adelberg. EGC. Jakarta. 1996. Hal 211-217,228,265267

5. Syah BT. Dalam: Rudolf, S., 2011. Hubungan Antara Faktor Usia dan Angka Kejadian Otitis Media Akut di RSUP H. Adam Malik Medan periode 2009 - 2010. Available from : http://repository.usu.ac.id/handle/123 456789/31375 Cited on 30 november 2014

6. World Health Organization, 2006. Primary ear and hearing care training resource: Advanced Level . WHO Geneva, Switzerland: WHO press, pp.14

7. Siew, Tan Hong. Karakteristik Penderita Otitisu Media Akut pada Anak. RSUP. Haji Adam Malik Medan. USU digital library 2011. Diakses melalui:http://repository.usu.ac.id/han dle/123456789/25640 Cited on 20 Januari 2014

8. Amaleen, Syaefah. Gambaran penderita Otitis Media Supuratif Akut. 2009. Diaksees melalui file://C:/Users/User/Downloads/9872 -18086-1-SM.pdf Cited on 20 Januari 2014. 